\title{
A TÁRSADALMI INNOVÁCIÓ VIZSGÁLATÁNAK TAPASZTALATAI ÉS FEJLESZTÉSI LEHETŐSÉGEI
}

Az innováció a gazdasági növekedés egyik meghatározó tényezője. A gazdasági szereplők már régóta felismerték, hogy olyan régiókban, ahol viszonylag alacsony szintű a gazdasági és természettudományi innováció, a társadalmi innováció előnyös kiegészítő tényező lehet. Jelen tanulmány bemutat egy közelítésmódot a társadalmi innovációs potenciál növelésének módszertanára vonatkozóan'. A tanulmány először jellemzi a társadalmi innovációk jelenlegi helyzetét. Ezután a cikk azzal foglalkozik, hogy milyen módszertani támogatással lehetne új társadalmi innovációkat generálni.

Kulcsszavak: társadalmi innovációs potenciál, tudásgenerálás, a gazdasági növekedés és az innováció kapcsolata

A hazai és a nemzetközi szakirodalomban elötérbe került a társadalmi innováció feltételrendszerének és hatásainak vizsgálata. Az empirikus vizsgálatok kimutatták, hogy közvetlen kapcsolat van egy település vagy régió gazdasági és innovációs teljesítménye között. Az innovációban élenjáró régiók gazdasági teljesítménye jelentősen meghaladja az innováció terén gyengébb eredményeket felmutató területekét. A régiók csak akkor tudják javítani versenyképességüket, ha magas hozzáadott értékü termékeket és szolgáltatásokat állítanak elő.

Nem véletlen, hogy az utóbbi két évtizedben az Európai Unió megváltoztatta innovációs politikáját, alapvetően azért, mert romlott a versenyképessége a világ más vezető régióihoz viszonyítva. Ennek következtében új célok, eszközök és módszerek jelentek meg, amelyek az „Európai Innovációs Klíma" javítását szolgálják. Az egyes országokon belüli régiók szintjén alapvető célkitűzés olyan regionális kutatási és technológiapolitika kialakítása, amely megfelel a régiók képességeinek, és amely összhangban van az Európai Unió decentralizációs elképzeléseivel. Felismerték, hogy szükség van a központi elképzelések régiók szintjére való lebontására, hogy hatékonyabban tudják generálni a területi innovációs folyamatokat.

Kettős feladatot kell megoldani: egyrészt növelni kell az EU versenyképességét, másrészt kezelni szükséges a növekvő társadalmi feszültségeket. E többcélú optimalizálási szándék következménye, hogy az Európai Unió a társadalmi kohéziót a közösségi politika szintjére emelte. Az 1. táblázat jól jelzi a probléma összetettségét, hiszen az új tagállamok csatlakozásával a területi különbségek tovább növekedtek.

Magyarországon is megfigyelhető, hogy a központi régióban a $\mathrm{K}+\mathrm{F}$ ráfordítás magasabb az átlagnál, míg a perifériákon a $\mathrm{K}+\mathrm{F}$ kiadások elmaradnak az átlagos mértéktől. A korábban középpontban álló müszaki-technológiai innováció mellett az értelmezési tartomány részét kell képezze a társadalmi innováció, ami elvezetett az innováció kibővített értelmezéséhez. Az Európai Unióban az elmúlt időszakban létrejött kutatóintézetek, az e témában kiírt pályázatok és az erre a célra elkülönített finanszírozási források nagyobb figyelmet fordítanak a társadalmi innováció kontextusára.
1. táblázat

A régiók megoszlása az egy före jutó GDP EU-átlag feletti és a $75 \%$ alatti régiók alapján

\begin{tabular}{|c|c|l|l|}
\hline Év & $\begin{array}{c}\text { NUTS2 régiók } \\
\text { száma }\end{array}$ & $\begin{array}{c}\text { Az egy fóre } \\
\text { jutó GDP } \\
\text { átlaga feletti } \\
\text { régiók száma }\end{array}$ & $\begin{array}{c}\text { Az egy fóre } \\
\text { jutó GDP } \\
75 \%-a \\
\text { alatti régiók } \\
\text { száma }\end{array}$ \\
\hline 1999 (EU 15) & 214 & $\begin{array}{l}128 \\
(60 \%)\end{array}$ & $\begin{array}{l}22 \\
(10 \%)\end{array}$ \\
\hline 2005 (EU 27) & 271 & $\begin{array}{l}129 \\
(47 \%)\end{array}$ & $\begin{array}{l}69 \\
(25 \%)\end{array}$ \\
\hline
\end{tabular}

Forrás: Benedek József - Kocziszky György - Veresné Somosi Mariann (2015): Új innovációs paradigma? Regionális társadalmi innovációs potenciál javitásának lehetősége szakértői rendszer segítségével, lehetőségek és korlátok. "Mérleg és Kihívások" IX. Nemzetközi Tudományos Konferencia, 2015. október 15-16. (247-255.o.)

\section{A kutatás célja}

Az EU-ban a társadalmi problémák visszatérőek, részben belső (növekvő jövedelmi különbségek, öregedés stb.), részben külső okok miatt (pl. a migrációs hullámok). A problémát aligha lehet egyszeri pénzügyi beavatkozással vagy időszakos projektekkel orvosolni. A gazdasági és a természettudományos innovációk területileg és szektorok szerint csoportosulnak, s ezeket a nemzetközi statisztikák is alátámasztják. Olyan tényezők, mint a képzettségi szint, az oktatási jellemzők, a kulturális intézmények fontos szerepet töltenek be a létrejövő klaszterekben. Ezek a tényezők a központi régiókban elönyös helyzeteket eredményeznek, míg a perifériális területek nehezen tudnak felzárkózni. Emiatt paradigmaváltásra van szükség. A természettudományos és müszaki területeken megvalósuló $\mathrm{K}+\mathrm{F}$ mellett - amelyek egyre nagyobb ráfordításokat igényelnek - új és a mai kor követelményeinek megfelelő megoldások kellenek a kis közösségek (települések, régiók) társadalmi és gazdasági problémáinak kezelésére.

Kutatásunkban a társadalmi innováció régióbeli sajátosságainak bemutatására, illetve a fejlesztést elősegítő módszertan kidolgozására koncentrálunk (1. ábra). 
A kutatás célja

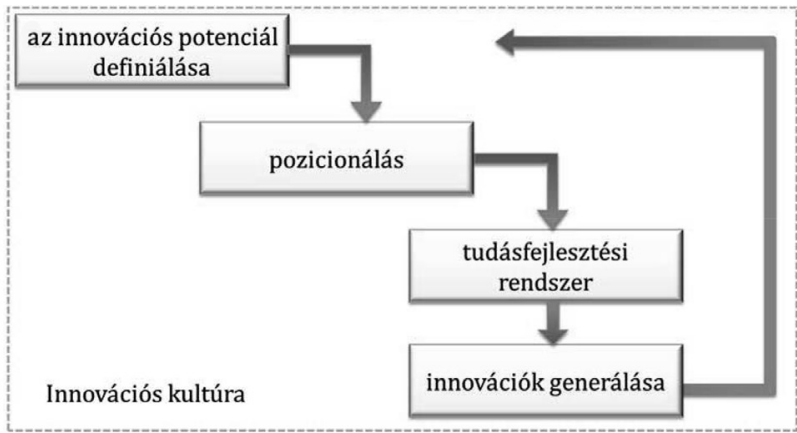

Forrás: Benedek József - Kocziszky György - Veresné Somosi Mariann (2015): Új innovációs paradigma? Regionális társadalmi innovációs potenciál javitásának lehetősége szakértői rendszer segítségével, lehetőségek és korlátok. „Mérleg és Kihívások” IX. Nemzetközi Tudományos Konferencia, 2015. október 15-16. (247.-255.0.)

\section{A társadalmi innováció fogalma}

A társadalmi innováció fogalmi megközelítései eltérőek, jelenleg sincs egységesen elfogadott definíciója. Releváns különbség a megközelítésekben a közösségi jólétnél, illetve a társadalmi problémákra adott újszerü megoldásoknál tapasztalható.

Mindezek figyelembevételével a társadalmi innovációt az alábbiak szerint értelmezzük: , A társadalmi innováció új vagy újszerủ válaszokat ad egy közösség problémáira azzal a céllal, hogy növelje a közösség jólétét."

A társadalmi innovációs potenciál azon képességek összessége, amelyek lehetőséget teremtenek a társadalmi innovációk létrehozására. Ez a megközelítés helytől, időtől és jövedelmi helyzettől függetlenül lehetőséget nyújt a társadalmi innovációk értelmezésére. A társadalmi innováció szükségletének hierarchiáját szemlélteti a 2. táblázat.

2. táblázat A társadalmi innováció szükséglethierarchiája

\begin{tabular}{|c|c|}
\hline $\begin{array}{l}\text { Szükségletek } \\
\text { hierarchiája }\end{array}$ & Potenciális problémák \\
\hline $\begin{array}{l}\text { - fiziológiai szükség- } \\
\text { letek }\end{array}$ & $\begin{array}{l}\text { - környezetszennyezés (víz, levegő } \\
\text { stb.) } \\
\text { - alultápláltság stb. }\end{array}$ \\
\hline $\begin{array}{l}\text { - biztonsági szükség- } \\
\text { letek }\end{array}$ & $\begin{array}{l}\text { - vagyonkockázat } \\
\text { - szenvedélybetegség (kábítószer, } \\
\text { alkohol stb.) } \\
\text { - munkahely, alapvető szükségletek } \\
\text { kielégítése }\end{array}$ \\
\hline \begin{tabular}{|l} 
- kapcsolati szükség- \\
letek
\end{tabular} & $\begin{array}{l}\text { - magányosság } \\
\text { - kizártság stb. }\end{array}$ \\
\hline - önbecsülés & - életképesség, kreativitás hiánya \\
\hline - önmegvalósítás & - szavahihetőség hiánya stb. \\
\hline
\end{tabular}

A társadalmi innovációkkal párhuzamosan a müszaki, természettudományi és gazdasági innovációk ugyancsak szükségesek. A két típus együttesen teszi lehetővé egy közösség gazdagságát és jólétét.

A társadalmi innováció definiálását követően fontos kérdés a társadalmi innováció tipológiájának összeállítása, mely a műszaki, gazdasági innovációk mintájára elkészíthető.

A társadalmi innováció hatása elsősorban hozzájárulhat a perifériális területeken és településeken élők életminőségének javításához, és segítheti a hátrányos társadalmi csoportokat. De a társadalmi innováció önmagában valószínüleg nem elegendő ahhoz, hogy egy alulfejlett közösség elérje a fejlettebbek színvonalát. A társadalmi és a természettudományi innovációk közötti szoros kapcsolatot illusztrálhatjuk a tipológiai hasonlóságokat bemutató ábrával (2. ábra).

2. ábra

\section{A társadalmi innováció kapcsolatrendszere}

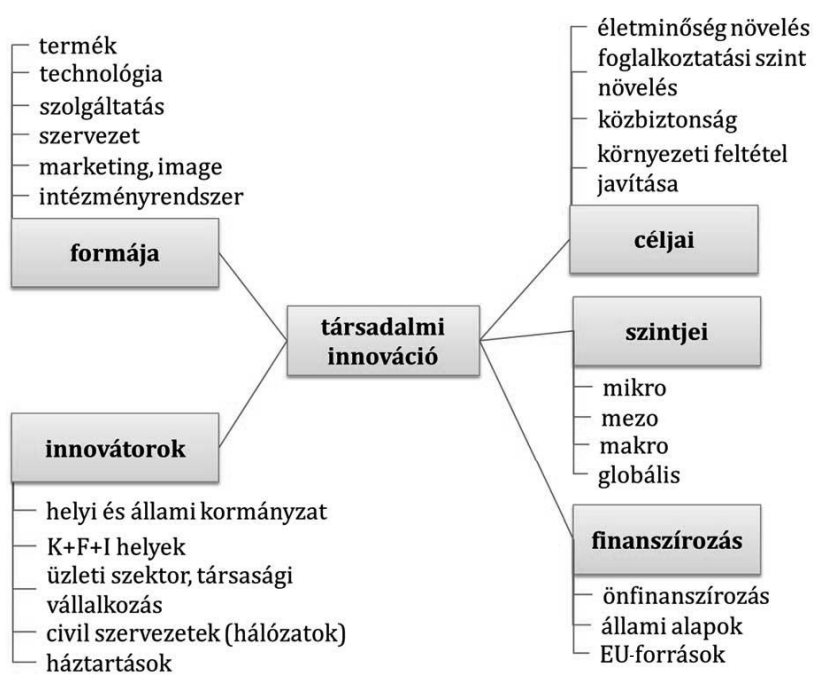

Forrás: saját szerkesztés

\section{A társadalmi innováció célja}

A társadalmi és a gazdasági innovációk komplex megközelítésében alapvetően a kitüzött célok és a tőkeigényesség szempontjából nevesíthetők jelentős különbségek. A társadalmi innováció célja egy magasabb életminőség elérése, amely megvalósítható a foglalkoztatási szint növelésével, valamint a közbiztonság és a környezeti feltételek javításával.

\section{A társadalmi innovátorok}

A társadalmi innováció egy társadalom valamennyi érintettjét (stakeholderét) befolyásolja (helyi és állami kormányzat, $\mathrm{K}+\mathrm{F}+\mathrm{I}$ helyek, üzleti szektor, ezen belül kiemelten a társadalmi vállalkozások, civil szervezetek, hálózatok, háztartások). Megállapítható, hogy ez esetben a szereplők köre bővül a hagyományos müszaki, gazdasági innovációk szereplőihez képest.

\section{A társadalmi innováció szintjei}

A társadalmi innováció definiálható mikro- (azaz szervezeti), mezo- (települések, kis régióbeli, megyei, regionális), makro- (nemzeti) és globális szinten. 


\section{A társadalmi innováció finanszírozása}

A társadalmi innováció finanszírozása alapvetően három forrásból valósul meg: önfinanszírozás, állami alapok és EU-források. Az EU az Európa 2020 stratégiájában (amely a lisszaboni stratégia folytatása) elkülönített pénzügyi forrásokat biztosít a társadalmi innovációs képességek javítására.

\section{Magyarország társadalmi innovációs potenciálja}

A 2007 és 2013 évek közötti időszakra elvégeztük a társadalmi innovációs potenciál elemzését Magyarország 19 NUTS3 megyéjére a KSH és a TEIR adatbázisokra támaszkodva. A 3. ábrán láthatók a vizsgálat indikátorcsoportjai: humán feltételek, intézményrendszer, telephelyi tényezők, aktivitás voltak.

\section{Input indikátorok}

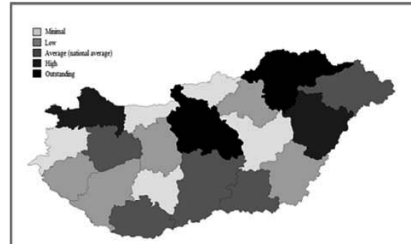

Az NGO-k eloszlása (2013)

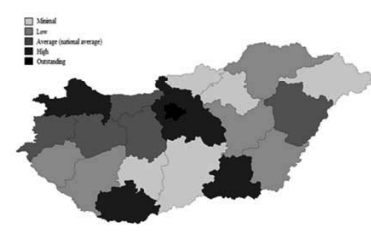

Átlagos képességi szint (2013)

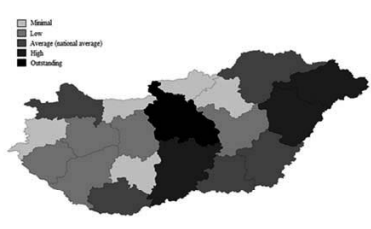

Vállalati sürüség (2013)

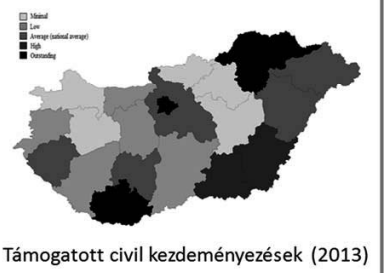

Forrás: Kocziszky György - Veresné Somosi Mariann - Balaton Károly (2015): Társadalmi innováció mérésének sajátosságai, „Mérleg és Kihívások” IX. Nemzetközi Tudományos Konferencia, 2015. október 15-16. (288.-302.o)

\section{Eredmények}

Társadalmi és gazdasági innovációs potenciáljuk alapján a magyar NUTS3 területek négy klaszterbe csoportosíthatók (4. ábra).

A gazdasági és társadalmi innováció szoros kapcsolatát jól szemléltetik a klaszterek, hiszen ahol gyenge színvonalú a gazdasági innováció, ott az tapasztalható, hogy a társadalmi innováció is alacsony szintủ.

\section{A tudásgenerálás fogalma és struktúrája}

A kialakított szakértői rendszer, analitikus képességeinél fogva, alkalmas arra, hogy meghatározza és súlyozza a problémákat, és egy lehetséges megoldást javasoljon a korábban rögzítettnek tekintett változatokkal szemben. A rendszer támogatja „ha..akkor” szabályok segítségével a tudásbankra építve a problémamegoldási folyamatot. Ezáltal a döntés-előkészítés hasznos támogatója lehet.

A javasolt tudásgenerálási rendszer két fö részből áll (5. ábra): egy felhasználói felület, amely lehetővé teszi adatok lekérését, csoportosítását és összehasonlítását (pl.: település, év stb.), valamint a számítások eredményeinek definiálását és bemutatását, szakértői javaslatok kidolgozását.

A magyar NUTS3 szintű gazdasági és társadalmi innovációs potenciál

4. ábra

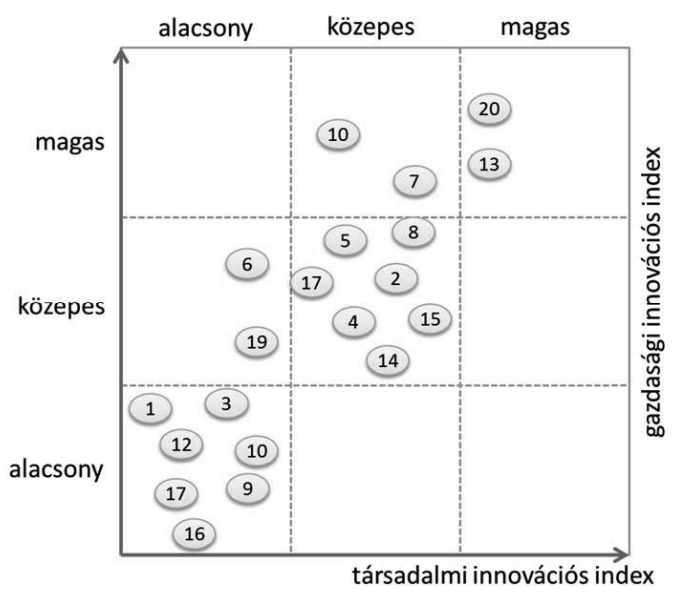

Jelölések:
1. Baranya
2. Bács-Kiskun
3. Békés
4. Borsod-Abaúj-Zemplén
5. Csongrád
6. Fejér
7. Győr-Moson-Sopron
8. Hajdú-Bihar
9. Heves
11. Komárom-Esztergom
10. Jász-Nagykun-Szolnok
13. Pest
12. Nógrád
15. Szabolcs-Szatmár-Bereg
17. Vas
14. Somogy
19. Zala
16. Tolna
18. Veszprém
20. Budapest

Forrás: Benedek József- Kocziszky György - Veresné Somosi Mariann (2015): Új innovációs paradigma? Regionális társadalmi innovációs potenciál javitásának lehetősége szakértői rendszer segítségével, lehetőségek és korlátok. "Mérleg és Kihívások" IX. Nemzetközi Tudományos Konferencia, 2015. október 15-16. (247.-255.o.)

\section{A társadalmi innováció tudásgenerálásának} struktúrája

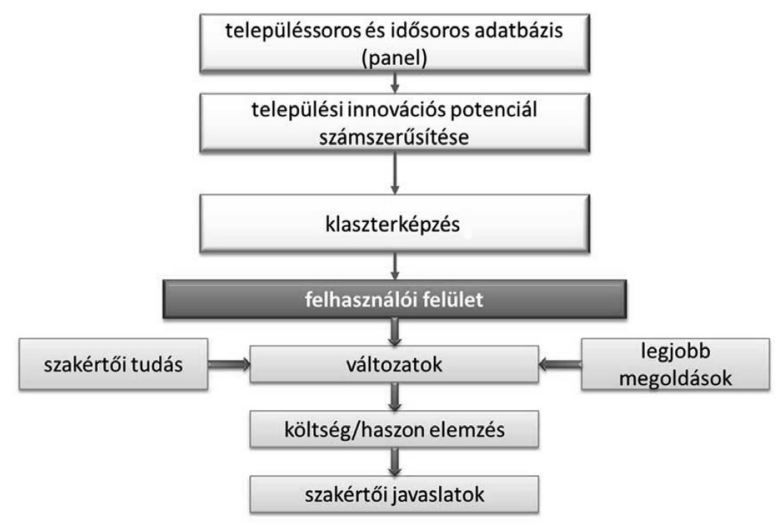

Forrás: Saját szerkesztés 
A továbbiakban a szakértöi rendszer müködéséböl két elemet kívánunk bemutatni, egyrészt azt a szempontrendszert (3. táblázat), amely a társadalmi innováció differenciált változatainak kijelölését és a szabályok megalkotását segítette, másrészt pedig a jó gyakorlatok tárából, elsősorban a fiatalokkal foglalkozó társadalmi innovációs megoldásokból (4. táblázat) adunk ízelítőt.

3. táblázat

\section{A társadalmi innovációt generáló szabályalapú szempontrendszer}

Társadalmi innovációs potenciál vizsgálati szempontjai

- a vizsgált szervezet termékeinek/szolgáltatásainak

korszerüségi színvonala,

- a jelenlegi tevékenység viszonyulása a szervezet korábbi tevékenységeihez,

- a termékek/szolgáltatások versenyképességének minősítése,

- termelési/szolgáltatási struktúra jellemzése,

- az elmúlt 2 év társadalmi innovációinak száma,

- megoldások a szervezet termék/szolgáltatás struktúrájának módosításához,

- a szervezet/társadalmi innovációhoz kapcsolódó termékeinek előnyei-hátrányai,

- a társadalmi innovációs termékek/szolgáltatások céljai/ célcsoportjai,

- társadalmi innovációs termékek/szolgáltatások föbb jellemzői,

- a szervezet társadalmi innovációs tevékenységét veszélyeztető konkurencia,

- új fejlesztési irányok a társadalmi innováció területén a szervezetben,

- a társadalmi innováció folyamatának gyenge pontjai, típushibái,

- a társadalmi innováció becsült aránya az árbevétel

vonatkozásában,

- a társadalmi innováció újdonságfokozatai,

- a társadalmi innováció termékeinek/szolgáltatásainak tartalomforrása,

- a társadalmi innováció termékeinek/szolgáltatásainak finanszírozási forrása,

- a társadalmi innováció ráfordítás forrásmegoszlása,

- a szervezet alkalmassága a társadalmi innovációs tevékenységre,

- a társadalmi innováció szempontjából releváns tényezők,

- a társadalmi innovációs folyamat gátló tényezői,

- a társadalmi innovációs szükséges információk forrásai,

- a társadalmi innováció során megvalósuló együttműködések,

- a társadalmi innovációba bevont külső szervezetek, személyek,

- a társadalmi innováció megvalósításában résztvevők,

- a szervezetnek a tudástranszfer-akciókban vállalt szerepe.

Forrás: Saját szerkesztés
4. táblázat

A fiatalokhoz kapcsolódó társadalmi innovációs jó gyakorlatok néhány példája

\begin{tabular}{|c|c|}
\hline \multicolumn{2}{|c|}{ Jó gyakorlatok tára } \\
\hline diák-elszállásolás & $\begin{array}{l}\text { egy-egy alapítvány létrehozása azok- } \\
\text { ban a városokban, ahol felsőoktatási } \\
\text { intézmény működik, melynek felada- } \\
\text { ta, diákok részére szállás kialakítása, } \\
\text { fenntartása }\end{array}$ \\
\hline $\begin{array}{l}24 \text { órás otthont nyújtó } \\
\text { szolgáltatás }\end{array}$ & $\begin{array}{l}\text { a szolgáltatás élvezői: egyedül élő } \\
\text { emberek (mentális betegeket is bele- } \\
\text { értve); azon emberek, akik intézmé- } \\
\text { nyekben élik normális életüket alacso- } \\
\text { nyabb költséggel; felnőttek, akik idős } \\
\text { szüleikkel élnek; sérült gyerekek }\end{array}$ \\
\hline $\begin{array}{l}\text { lakásfenntartó vállalati } \\
\text { modell }\end{array}$ & az épület tulajdonosi joga a vállalaté \\
\hline $\begin{array}{l}\text { gyermekek napközbe- } \\
\text { ni ellátása }\end{array}$ & $\begin{array}{l}\text { helyi hatóságok kötelezettsége a gyer- } \\
\text { mekek napközbeni ellátása, ennek a } \\
\text { támogatása szolgáltatással, melyet a } \\
\text { szülők vehetnek igénybe }\end{array}$ \\
\hline gondozói támogatás & $\begin{array}{l}\text { különböző esetei értelmezhetők (pél- } \\
\text { dául, ha egy személy gyógyszeres } \\
\text { kezelésre vagy betegség, mozgáskép- } \\
\text { telenség, törés vagy hasonló okból } \\
\text { ápolásra szorul és családtag vagy } \\
\text { hozzátartozó felelősséget vállal érte } \\
\text { megfelelő szolgáltatások segítségével) }\end{array}$ \\
\hline $\begin{array}{l}\text { egyetemisták egész- } \\
\text { ségügyi szolgálata }\end{array}$ & $\begin{array}{l}\text { egyetemisták részére külön egész- } \\
\text { ségügyi szervezet létrehozása, } \\
\text { mely egészségügyi és gyógyszeres } \\
\text { kezelést biztosít, valamint mentális } \\
\text { egészségügyi és fogászati szolgál- } \\
\text { tatásokat is; célja a diákok tanulási } \\
\text { képességének fenntartása, növelése, } \\
\text { egészségük megőrzésével, betegségek } \\
\text { megelőzésével }\end{array}$ \\
\hline tanulói segélyek & $\begin{array}{l}\text { elmaradott régiók tanulóinak célzott } \\
\text { támogatása, melyet csak akkor kap a } \\
\text { diák, ha teljesíti a követelményeket; } \\
\text { visszafizetendő, ha máshonnan elég } \\
\text { jövedelemhez jut }\end{array}$ \\
\hline $\begin{array}{l}\text { fejlesztési együttmü- } \\
\text { ködés regionális szol- } \\
\text { gáltató központ }\end{array}$ & $\begin{array}{l}\text { nem kormányzati szervezetek tu- } \\
\text { dástranszferáló szervezete, kapocs az } \\
\text { állami szervek és a civil társadalom } \\
\text { közti együttműködésre }\end{array}$ \\
\hline $\begin{array}{l}\text { önkéntes munka } \\
\text { mozgalom }\end{array}$ & $\begin{array}{l}\text { az önkéntes munkavégzés kiterjeszté- } \\
\text { se az egyetemisták körére }\end{array}$ \\
\hline
\end{tabular}

Forrás: Saját szerkesztés

A szakértők konzultációt nyújtanak, mint a rendszer partnerei. Javaslatokat tehetnek a társadalmi innováció fejlesztésére a saját tudásuk, tapasztalataik és szakirodalmi ismereteik alapján.

\section{Következtetések}

Az elmúlt években paradigmaváltás következett be az innováció kutatásában. A kialakuló innovációs paradigma fö jellemzői az alábbiakban foglalhatóak össze: 
- a társadalmi innováció jelentősége nem kisebb, mint a gazdasági és természettudományi innovációké,

- a gazdasági és természettudományi innovációk társadalmi problémákat idéznek elő, amelyek csak társadalmi innovációk segítségével oldhatók meg,

- szoros együttmüködés szükséges a társadalmi és a műszaki/természettudományos innovációk között,

- a társadalmi innovációk generálása és menedzselése ugyancsak költséges, hasonlóan, mint a többi típusú innovációk esetében,

• szükséges az erőforrások felhasználásának évenként figyelemmel kísérése.

A társadalmi innováció mérése és a monitoring segítheti az ez irányú tevékenységeket, és hozzájárulhat a szükséges beavatkozások irányainak kijelöléséhez.

\section{Jegyzet}

1 A szerzők köszönetet mondanak Prof. Benedek Józsefnek a tanulmány korábbi változatának elkészítésében való közremüködésért.

\section{Felhasznált irodalom}

Analysis of SME Needs (1996): Analysis of SME Needs Methodology in Design, Construction and Operation. Regional Technology Frameworks. Volume I. EIMS Publication No. 18, EC DG XIII.

Balaton K. (2005): Vállalati stratégiák és szervezetek a rendszerváltást követően. Budapest: Aula Kiadó

Benedek József- Kocziszky György - Veresné Somosi Mariann (2015): Új innovációs paradigma? Regionális társadalmi innovációs potenciál javításának lehetősége szakértői rendszer segítségével, lehetőségek és korlátok. „Mérleg és Kihívások” IX. Nemzetközi Tudományos Konferencia, Miskolc, 2015. október 15-16. (247.-255.o.)

Camagni, R. P. (1995): The Concept of Innovative Milieu and its Relevance for Public Policies in European Lagging Regions. Papers in Regional Science. The Journal of the RSAI, 74, 4, p. 317-340. 10.1111/j.1435-5597.1995. tb00644.x

Clar, G. - Corkapis, D. - Landabaso, M. (2001): Mobilizing Regional Foresight Actors to Strengthen the Strategic Basis of the European Research Area. IPTS Report, No. 59, p. 38-45.

Cook, P. - di Marchi, B. (2002): Generative Growth, Knowledge Economies und Sustainable Development: Implications for Regional Foresight Policy. EC STRATA ETAN Working Group Papers

EC (1995): Green Paper on Innovation. Brussels: European Commission

EC (2002b): A Practical Guide to Regional Foresight in Ireland. Brussels: EU Commission

EC (2010): Európa 2020. Az intelligens, fenntartható és inkluzív növekedés stratégiája. Brüsszel: Európai Bizottság, 03/03/2010
EC (2014): Strengthening social innovation in Europe. Brussels: European Commission

Eggert, W. (Hrsg.) (2014): Gabler Wirtschaftslexikon. Berlin: Springer Gabler Verlag. 10.1007\%2F978-3-66301439-3

EP (2006): A Tanács 1084/2006/EK rendelete (2006. július 11.) a Kohéziós Alap létrehozásáról és az 1164/94/ EK rendelet hatályon kívül helyezéséről.

European Commission (1992): Towards a Europe of solidarity. Intensifying the struggle against social exclusion, furthering social integration. COM (92) 542

European Commission (1993): The Future of European Social Policy: Options for the Union. A Green Paper. COM (93) 551.

European Commission (2005): Communication from the Commission on the Social Agenda. COM (2005) 33.

Ewers, H. J. - Brenck, A. (1992): Innovationsorientierte Regionalpolitik. Zwischenfazit eine Forschungsprogramms. in: Birgh, H. - Schalk, H. J. (Hrsg.) (1992): Regionale und sektorale Strukturpolitik, Münster, S., p. 309-341.

FOREN (2001): A Practical Guide to Regional Foresight, Foresight for Regional Development Network. Brussels: European Commission, Research Directorate General, Strata Programme

Frascati Manual (1963): Paris: OECD, Frascati kézikönyv. OMFB. Bp. 1996

Gillwald, K. (2000): Konzepte Soziale Innovation. Berlin: WZB

Howaldt, J. - Schwarz, M. (2010): Soziale Innovation im Fokus. Skizze eines gesellschafts-theoretisch inspirierten Forschungskonzepts. Bielefeld: Transcript Verlag, 10.14361/transcript.9783839415351

Kocziszky Gy. (2004): Az Észak-magyarországi régió innovációs potenciáljának vizsgálata. Észak-magyarországi Stratégiai Füzetek. Nr.1. Miskolc: Miskolci Egyetem, p. 5-39.

Kocziszky György - Veresné Somosi Mariann - Balaton Károly (2015): Társadalmi innováció mérésének sajátosságai. „Mérleg és Kihívások” IX. Nemzetközi Tudományos Konferencia, Miskolc, 2015. október 15-16. (288.-302.o)

Moulaert, F. (2013): The international handbook of social innovation: collective action, social learning and transdisciplinary research. Cheltenham, Northampton: Edward Elgar. 10.4337/9781849809993

Ogburn, W. F. (1957): Cultural Lag as Theory. Sociology and Social Research, 41., p. 167-174.

Ogburn, W. F. (1964): On Culture and Social Change. Chicago: University of Chicago Press

Puppe, F. (1991): Einführung in Expertensysteme. Berlin: Springer Verlag, 10.1007/978-3-642-76621-3

Whyte, W. (1982): Social inventions for Solving Human Problems. American Sociological Review, 47 (1), p. $1-13$.

Zapf, W. (1989): Über soziale Innovationen. Soziale Welt, 40 H. 1-2, p. 170-183. 